\title{
Major peptide autoepitopes for nucleosome-specific T cells of human lupus
}

\author{
Liangjun Lu, ${ }^{1}$ Arunan Kaliyaperumal, ${ }^{1}$ Dimitrios T. Boumpas, ${ }^{2}$ and Syamal K. Datta ${ }^{1}$ \\ ${ }^{1}$ Departments of Medicine and Microbiology-Immunology, Northwestern University Medical School, \\ Chicago, Illinois 60611, USA \\ ${ }^{2}$ Arthritis and Rheumatism Branch, National Institutes of Health, Bethesda, Maryland 20892, USA \\ Address correspondence to: Syamal K. Datta, Arthritis Division, Ward 3-315, Northwestern University Medical School, \\ 303 East Chicago Avenue, Chicago, Illinois 60611-3008, USA. Phone: (312) 503-8003; Fax: (312) 503-0994; \\ E-mail: skd257@nwu.edu.
}

Received for publication March 12, 1999, and accepted in revised form June 29, 1999.

\begin{abstract}
We tested 154 peptides spanning the entire length of core histones of nucleosomes for the ability to stimulate an anti-DNA autoantibody-inducing $\mathrm{T}$ helper $(\mathrm{Th})$ clone, as well as $\mathrm{CD} 4^{+} \mathrm{T}$-cell lines and $\mathrm{T}$ cells, in fresh PBMCs from 23 patients with lupus erythematosus. In contrast to normal $\mathrm{T}$ cells, lupus $\mathrm{T}$ cells responded strongly to certain histone peptides, irrespective of the patient's disease status. Nucleosomal peptides in histone regions $\mathrm{H}_{2} \mathrm{~B}_{10-33}, \mathrm{H} 4_{16-39}$ (and overlapping $\mathrm{H} 4_{14-28}$ ), $\mathrm{H} 4_{71-94}$, and $\mathrm{H}_{91-105}$ (and overlapping $\mathrm{H}_{100-114}$ ) were recurrently recognized by CD4 $\mathrm{T}$ cells from the patients with lupus. Remarkably, these same peptides overlap with major epitopes for the Th cells that induce antiDNA autoantibodies and nephritis in lupus-prone mice. We localized 2 other recurrent epitopes for human lupus $\mathrm{T}$ cells in $\mathrm{H}_{2} \mathrm{~A}_{34-48}$ and $\mathrm{H}_{49-63}$. All the T-cell autoepitopes have multiple HLA-DR binding motifs, and the epitopes are located in histone regions recognized by lupus autoantibodies, suggesting a basis for their immunodominance. Native nucleosomes and their peptides $\mathrm{H} 4_{16-39}, \mathrm{H} 4_{71-94}$, and $\mathrm{H} 3_{91-105}$ induced a stronger IFN- $\gamma$ response, whereas others, particularly, $\mathrm{H} 2 \mathrm{~A}_{34-48}$, favored an IL10- and/or IL-4-positive T-cell response. The major autoepitopes may reveal the mechanism of autoimmune T-cell expansion and lead to antigen-specific therapy of human lupus.
\end{abstract}

J. Clin. Invest. 104:345-355 (1999).

\section{Introduction}

A select population of autoimmune T helper (Th) cells drives B cells to produce pathogenic anti-DNA autoantibodies in systemic lupus erythematosus (SLE) (1-3). To identify their immunogen(s), the autoimmune Th cells of lupus were cloned from patients with SLE, as well as from the $(\mathrm{SWR} \times \mathrm{NZB}) \mathrm{F}_{1}\left(\mathrm{SNF}_{1}\right)$ mice that spontaneously develop lupus nephritis $(1,2,4-6)$. In lupusprone mice, a majority of such pathogenic Th clones respond to nucleosomal antigens, and nucleosome-specific $\mathrm{T}$ cells are detectable early in the mice, long before they begin to produce pathogenic autoantibodies $(3,6$, 7). Pathogenic autoantibody-inducing Th cells of human lupus are also specific for nucleosomal antigens $(3,8)$, and nucleosome-specificity of the autoantibodies that are induced by such Th cells probably mediates glomerular binding and the development of lupus nephritis $(6,9-12)$. Thus nucleosomes are primary immunogens that might initiate the cognate interaction between pathogenic Th and B cells of lupus. Nucleosomes can be released from apoptotic cells even in normal subjects $(13,14)$, but the spontaneous expansion of nucleosome-reactive $\mathrm{T}$ cells occurs in lupus-prone mice $(6,7)$. These Th cells are essential for sustaining the pathogenic autoantibody-producing B cells of lupus $(15,16)$. Herein, we have identified the peptide autoepitopes in nucleosomes that are recurrently recognized by the autoimmune $\mathrm{T}$ cells of patients with SLE.

\section{Methods}

Patients and healthy donors. Short-term CD4 T-cell lines were derived from 5 patients with active lupus (all female; aged $18-50$ years), 5 patients in long-term remission (all female; aged 21-51 years), and 6 normal (healthy) subjects (2 male and 4 female; aged 24-52 years), as described previously (17). PBMCs from another set of 8 patients with lupus in long-term remission $(2$ male and 6 female; aged 28-55 years), and 4 patients with active lupus (all female; aged 22-47 years), were studied directly for intracellular cytokine production. Disease activity by Systemic Lupus Activity Measure (SLAM; ref. 18) ranged between 7 and 20 for patients with active lupus. None of the patients in remission had detectable proteinuria or serum anti-DNA autoantibodies at the time of testing, and their SLAM ranged between 0 and 4 . The patients in remission had never received any cytotoxic drugs. Steroids had been discontinued for several years in the patients in remission, except for 2 who had received a short course of low-dose steroids (prednisone, $10 \mathrm{mg} / \mathrm{d}$ ) 2 months before their blood samples were drawn for the assays.

Antibodies. Anti-CD3 (OKT3) mAb was obtained from American Type Culture Collection (Rockville, Maryland, USA). Anti-CD28 mAb (clone 9.3) was provided by Kathy Cabrian (Bristol-Myers Squibb, Seattle, Washington, USA). Purified mAb's for ELISA, phycoerythrinconjugated (PE-conjugated) $\mathrm{mAb}$ to human IL-10, and 

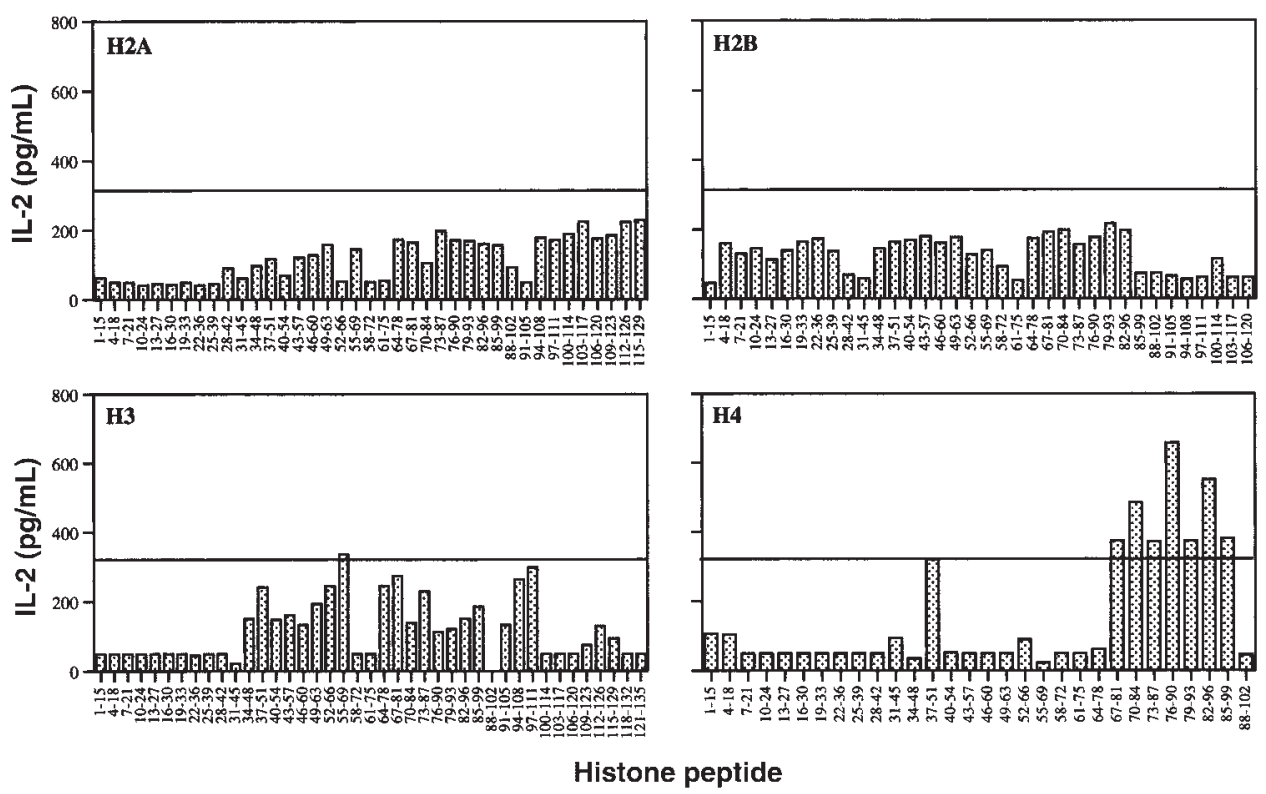

Figure 1

IL-2 production by anti-DNA autoantibody-inducing T-cell clone DD2 in response to nucleosomal histone peptides (10 $\mu \mathrm{M}$ each) presented by autologous EBV B-cell APCs. Bars represent mean of triplicate values. Values higher than 3 SD (horizontal line) above the mean of background (DD2 + APCs without added peptide produced $132 \mathrm{pg} / \mathrm{mL}$ IL-2) were considered as stimulatory. IL-2 production by DD2 in response to anti-CD3 stimulation was $554 \mathrm{pg} / \mathrm{mL}$.

FITC-conjugated $\mathrm{mAb}$ to human IL-2 were from PharMingen (San Diego, California, USA). PE-conjugated $\mathrm{mAb}$ to human IL-4, FITC-conjugated $\mathrm{mAb}$ to human IFN- $\gamma$, peridinin chlorophyl protein (PerCP) anti-human CD4, and purified anti-human CD28 (clone L293) were from Becton Dickinson Immunocytometry Systems (San Jose, California, USA).

Antigens. All peptides were synthesized by pin method (Chiron Mimotopes, San Diego, California, USA), and their purity was checked by amino acid analysis (7). Overlapping 15-mer peptides were synthesized spanning the entire stretch of all 4 core histones in nucleosomes, and each overlapped the preceding amino acid by 12 residues (7). Peptides used for intracellular cytokine response studies were also 15 mer, except for 3 longer (24-mer) histone peptides ( $\mathrm{H}_{2} \mathrm{~B}_{10-33}, \mathrm{H} 4_{16-39}$, and $\left.\mathrm{H}_{71-94}\right)$ that were also used. Nucleosomes were prepared as described $(6,7)$.

Cell preparation. PBMCs from patients or healthy donors were isolated as described $(1,17)$. Aliquots of these cells were used to make short-term T-cell lines and Epstein-Barr virus-transformed (EBV-transformed) B-cell lines. Others cells were either used directly for stimulation with antigens or frozen into liquid nitrogen. To make short-term CD4 T-cell lines, $\mathrm{CD}^{+}$cells were selected from PBMCs using anti-CD4 $\mathrm{mAb}$-coupled magnetic beads and then freeing them by using DetachBeads (Dynal Inc., Oslo, Norway). The CD4 $\mathrm{T}$ cells were expanded by 1 round of stimulation with plate-bound anti-CD3 and anti-CD28 (clone 9.3) $\mathrm{mAb}$ 's and with recombinant IL-2 (20 U/mL) in RPMI1640 with $10 \%$ human AB serum (Pel-Freez Biologicals, Brown Deer, Wisconsin, USA). The expanded T cells were frozen in liquid nitrogen within 2 weeks of culture. EBV B-cell lines for use as antigen-presenting cells (APCs) were made as described $(2,3)$.

Stimulation of short-term T-cell lines. Short-term line T cells were rapidly thawed from liquid nitrogen and expanded once again with plate-bound anti-CD3 and anti-CD28 mAb's and recombinant IL-2 $(20 \mathrm{U} / \mathrm{mL})$. The cells were then removed to new culture wells and rested in fresh medium for 10-14 days. For stimulation assays, 96-well plates were coated with goat anti-mouse IgG antibodies $\left(2 \mu \mathrm{g} / \mathrm{mL}\right.$ ) overnight at $37^{\circ} \mathrm{C}$. (This antibody would cross-link the mouse anti-human CD28 $\mathrm{mAb}$ that would be added later.) After washing twice with Dulbecco's PBS, autologous irradiated (30 Gy) EBV B cells ( $10^{5} /$ well) were first added into wells and cultured together with different histone peptide antigens or control peptides for 6 hours in HL-1 serum-free medium (BioWhittaker Inc., Walkersville, Maryland, USA). This antigen-pulsing was followed by addition of CD4 T cells $\left(10^{5} / \mathrm{mL}\right)$ from the short-term lines into the wells together with $0.5 \mu \mathrm{g} / \mathrm{mL}$ mouse anti-human $\mathrm{CD} 28 \mathrm{mAb}$. The final volume of the cultures was 200 $\mu \mathrm{L} /$ well. After 24 hours of culture at $37^{\circ} \mathrm{C}, 100 \mu \mathrm{L}$ supernatant was carefully collected from each well for an IL ELISA, without removing the cells. The cell cultures were continued with freshly added medium (100 $\mu \mathrm{L}$ containing $20 \mathrm{U} / \mathrm{mL}$ recombinant IL-2) for a total of 72 hours, followed by addition of $\left[{ }^{3} \mathrm{H}\right]$ thymidine for another 18 hours. Incorporated radioactivity was measured as described (3). HLA class II dependence of antigen-specific responses of the CD4 $\mathrm{T}$ cells was determined by blocking with a panel of mAb's to HLA class II molecules as described (3). The pathogenic autoanti- 
body-inducing T-cell clone DD2 from a patient with lupus nephritis $(2,3)$ was similarly tested.

ELISA for IL-2 secretion. Anti-human IL-2 capture and biotinylated antibody pairs and standards were from PharMingen. ELISA was performed according to the manufacturer's instructions.

Direct stimulation of PBMCsex vivo. Measurements of antigen-specific, intracellular cytokine responses of $\mathrm{T}$ cells were done as described with slight modifications (19-21). Purified PBMCs $\left(10^{6}\right)$ were placed in polystyrene tissue culture tubes $(12 \times 75 \mathrm{~mm}$; Becton Dickinson and Co., Franklin Lakes, New Jersey, USA) containing $0.5 \mathrm{~mL}$ of HL-1 serum-free medium supplemented with $100 \mathrm{U} / \mathrm{mL}$ penicillin, $100 \mu \mathrm{g} / \mathrm{mL}$ streptomycin, and $2 \mu \mathrm{mM}$ L-glutamine (GIBCO BRL; Grand Island, New York, USA), appropriately titered peptide antigen preparations, and 1 $\mu \mathrm{g} / \mathrm{mL}$ anti-CD28 mAb, L293 (Becton-Dickinson and Co.). Anti-CD3 mAb was added to a duplicate set of cultures as a positive control. Culture tubes were incubated for 18 hours. Brefeldin A (final concentration $1 \mu \mathrm{g} / \mathrm{mL}$; Sigma Chemical Co., St. Louis, Missouri, USA) was added to the tubes for the last 17 hours of incubation.

Flow cytometry analysis. Staining of PBMCs for intracellular cytokines and surface markers was done as described (19-21). Five parameter analyses were per-

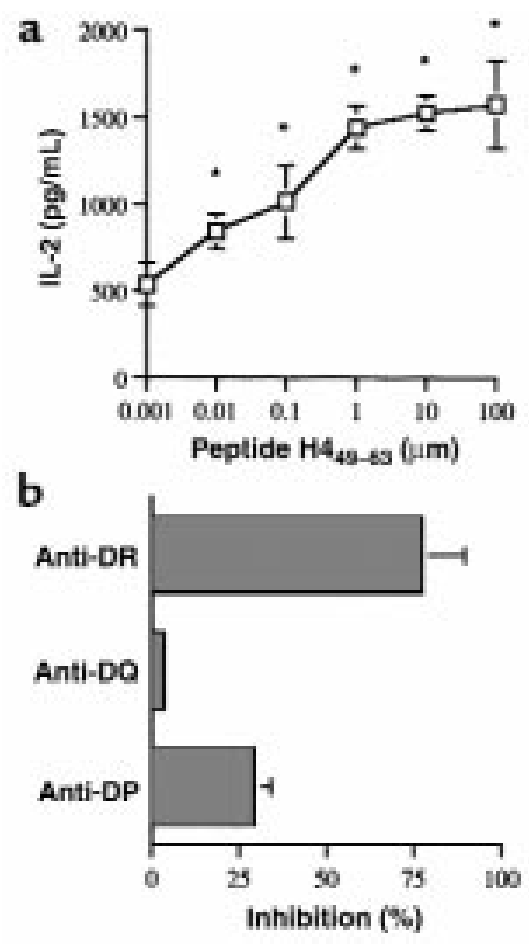

\section{Figure 2}

(a) IL-2 production by a representative short-term CD4 T-cell line L$\mathrm{EB}$, with different concentrations of histone $\mathrm{H}_{449-63}$ peptide-pulsed autologous EBV B-cell APCs. Stimulation with $0.01-100 \mu \mathrm{M}$ peptide showed significant differences ( ${ }^{*} P<0.05$ at $0.01 \mu \mathrm{M}$, Student's $t$ test) from background (T cells plus APCs cultured without peptide). (b) An example of $\mathrm{MHC}$ class II-dependent recognition of nucleosomal peptides. Presentation of $\mathrm{H}_{49-63}$ peptide by autologous EBV B cells to short-term T-cell line L-EB was inhibited mainly by anti-DR mAb. formed on FACScalibur (Becton Dickinson Immunocytometry Systems) using FITC, PE, and PerCP as the fluorescent parameters. Methods of cytometer setup and data acquisition have been described previously $(1$, 17, 19-21). For each analysis, 10,000 events were acquired and gated on CD4 expression and a light scatter gate designed to include only viable lymphocytes (1, $17,19)$. Isotype-matched negative control reagents were used for setting markers to delineate "positive " and "negative" populations.

\section{Results}

Response of an anti-DNA autoantibody-inducing lupus Th-cell clone to histone peptides. We first tested the response of a well-characterized CD4 T-cell clone, DD2, that was derived from a patient with active lupus nephritis $(2,3)$. DD2 induces the production of a pathogenic variety of anti-DNA autoantibodies when cocultured with autologous B cells, and it recognizes nucleosomes (3). Like other pathogenic autoantibody-inducing Th clones of human and murine lupus, DD2 bears charged residues in CDR3 loops of its T-cell receptor (TCR) $\alpha$ and $\beta$ chains, and it uses a member of the V $\alpha 8$ family $(3,22)$. A shown in Figure 1, DD2 can be stimulated by histone H4 peptides located in amino acid positions 67-99. The other nucleosomal histone peptides did not stimulate $\mathrm{DD} 2$, except for $\mathrm{H}_{55-69}$, which stimulated very weakly. These results confirmed autoantigenic specificity of DD2, as tested previously with whole antigens (3), and demonstrated that the peptide epitope scanning (pepscan) with synthetic histone peptides would work for human lupus T cells.

Localization of major peptide epitopes for autoimmune $T$ cells by using short-term CD4 T-cell lines. To narrow down the histone regions, we used short-term CD4 lines first because a large number of cells were required to scan the entire library of overlapping peptides spanning all the nucleosomal core histones. Dose-response curves were determined after localizing stimulatory histone peptides for the respective T-cell lines. A representative example is shown in Figure 2a. On the basis of these studies, we used 10- $\mu \mathrm{M}$ peptides in further experiments. The short-term lupus T-cell lines were also tested for HLA-class II dependence for antigen recognition and were found to recognize their respective peptide epitopes presented by HLA-DR molecules. A representative example is shown in Figure $2 \mathrm{~b}$.

Altogether, 10 short-term CD4 T-cell lines derived from patients with lupus and 6 such lines derived from healthy donors were tested for IL-2 response to 154 histone peptides presented by autologous EBV B-cell lines. Response of a representative short-term T-cell line (LSC) derived from a patient with lupus is shown in Figure 3 , and the results of short-term T-cell line (N-JV) derived from a normal control donor are shown in Figure 4. All the short-term T-cell lines from normal donors showed very weak and insignificant responses to the histone peptides (Figure 4). By contrast, the lupus T-cell lines, which were also polyclonal, responded 

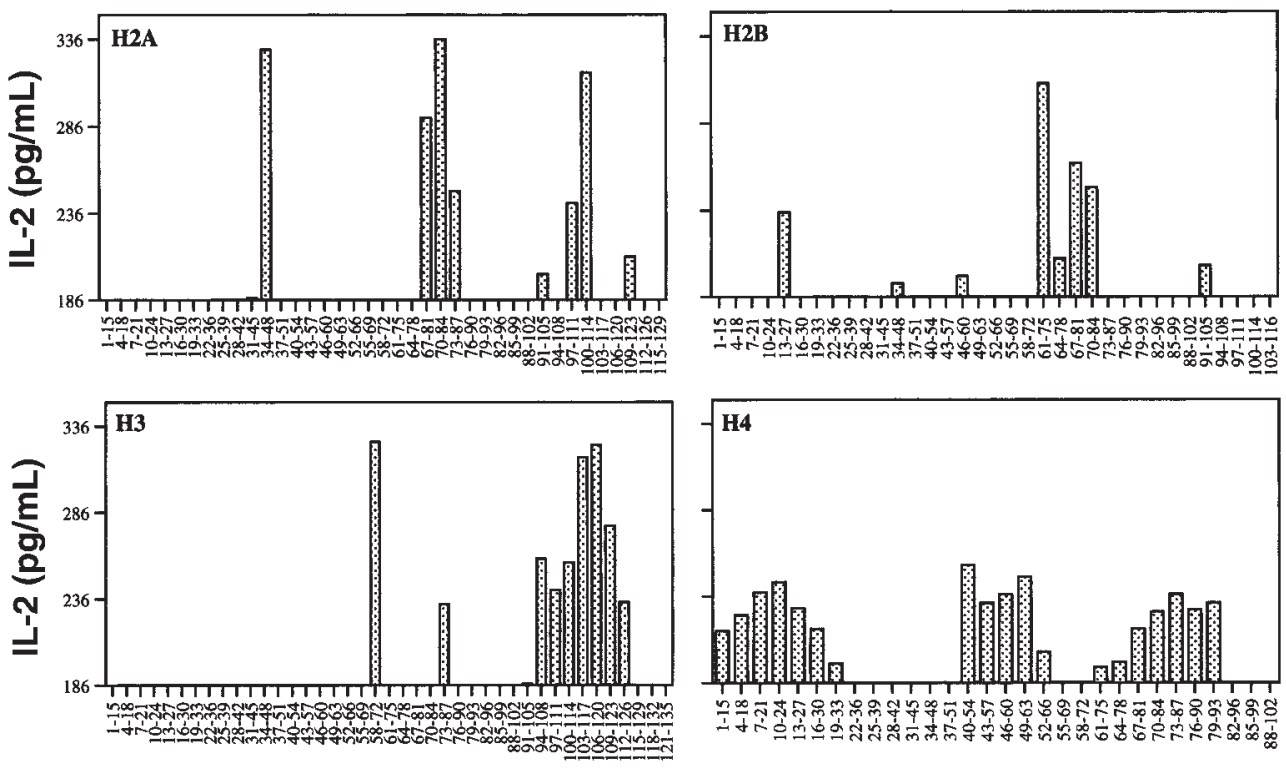

Histone peptide

\section{Figure 3}

Example of a pepscan of L-SC, a short-term CD4 T-cell line from a patient with lupus, with histone peptides presented by autologous EBV B-cell APCs. The baseline for $y$ axis is set at 3 SD above the mean of background values obtained with T cells cultured with APCs alone. IL-2 production responses to peptides above that value are shown.

strongly to peptides corresponding to certain regions in the core histones (Figure 3). A summary of significant responses of all the short-term $\mathrm{T}$-cell lines derived from 10 different patients with lupus is shown in Figure 5. These pepscan results localize the epitopes recognized consistently and recurrently by autoimmune $\mathrm{T}$ cells from different patients (Figure 5). There were no discernible differences between the responses of T-cell lines derived from patients with active lupus and from those with inactive lupus. Results of proliferative responses of the $T$ cells to the nucleosomal peptides were consistent with their IL-2 production responses (data not shown).

On the basis of the consensus stimulatory epitope regions identified by using the lupus $\mathrm{T}$-cell lines and clone DD2 (Figures 1-5), we selected sixteen 15-mer peptides (Figure 6) for further testing of $T$ cells directly in PBMCs of patients with lupus and of normal subjects. For further studies, we also used 3 longer (24mer) peptides that overlapped some of these epitopes and were found to be relevant to pathogenic Th and $\mathrm{B}$ cells of lupus-prone mice (refs. 7, 23; Figure 6).

Histone peptide epitopes for CD 4 T cells in PBMCs of patients with lupus. We wanted to confirm that the peptide autoepitopes (Figure 6) were also relevant to unmanipulated CD4 T cells in PBMCs of patients with lupus. Flow cytometry for newly synthesized, intracellular cytokines is ideal for rapidly detecting antigen-specific responses and determining the frequency of $\mathrm{CD} 4 \mathrm{~T}$ cells response to a particular epitope (19-21). Because autoimmune $T$ cells are preactivated in vivo in patients with active disease, we found that activation markers, such as CD69, CD25, or CD79, were not as reliable. We also optimized the intracellular cytokine assay by pro- viding costimulatory signal via CD28, which did not cause any nonspecific background stimulation, as described (19). Moreover, this method could be applied directly to PBMCs without T-cell purification. Intracellular production of newly synthesized IFN- $\gamma$, IL-2, IL-10, and IL-4 was assayed in response to the panel of peptide epitopes in Figure 6. As an additional background control, we used the $\mathrm{H}_{83-97}$ peptide, which, although being partly within a stimulatory region in $\mathrm{H} 3$ (Figure 6), was not recognized by any of the T-cell lines or clone DD2 (Figures 1-5). Two representative cytokine staining profiles from patients R-WG and R-SC are shown in Figure 7. Cells positive for a particular cytokine form a discrete population; single cells producing more than one cytokine were rare in these fresh PBMCs.

The results of intracellular cytokine production response of CD4 T cells in PBMCs from 12 patients with lupus are shown in Figure 8. Eight patients in remission and 4 patients with active disease, designated by prefixes, R- and A-, respectively, were studied. Results from 7 normal controls, designated by $\mathrm{N}$-, are shown in Figure 9. The absolute numbers of CD4 T cells were comparable in the PBMCs of patients with lupus in remission and those from normal subjects. An equal number of events from every sample were analyzed. After doing preliminary studies with test antigens, such as tetanus toxoid, mumps, and candida, and taking into account previous experience in other systems (19-21), we considered a response to the nucleosomal antigens to be unequivocally positive when the frequency of positive cells was greater than $0.2 \%$ and the values were at least 2 -fold higher than respective background values ("medium"; Figures 8 and 9). Repeat assays with 

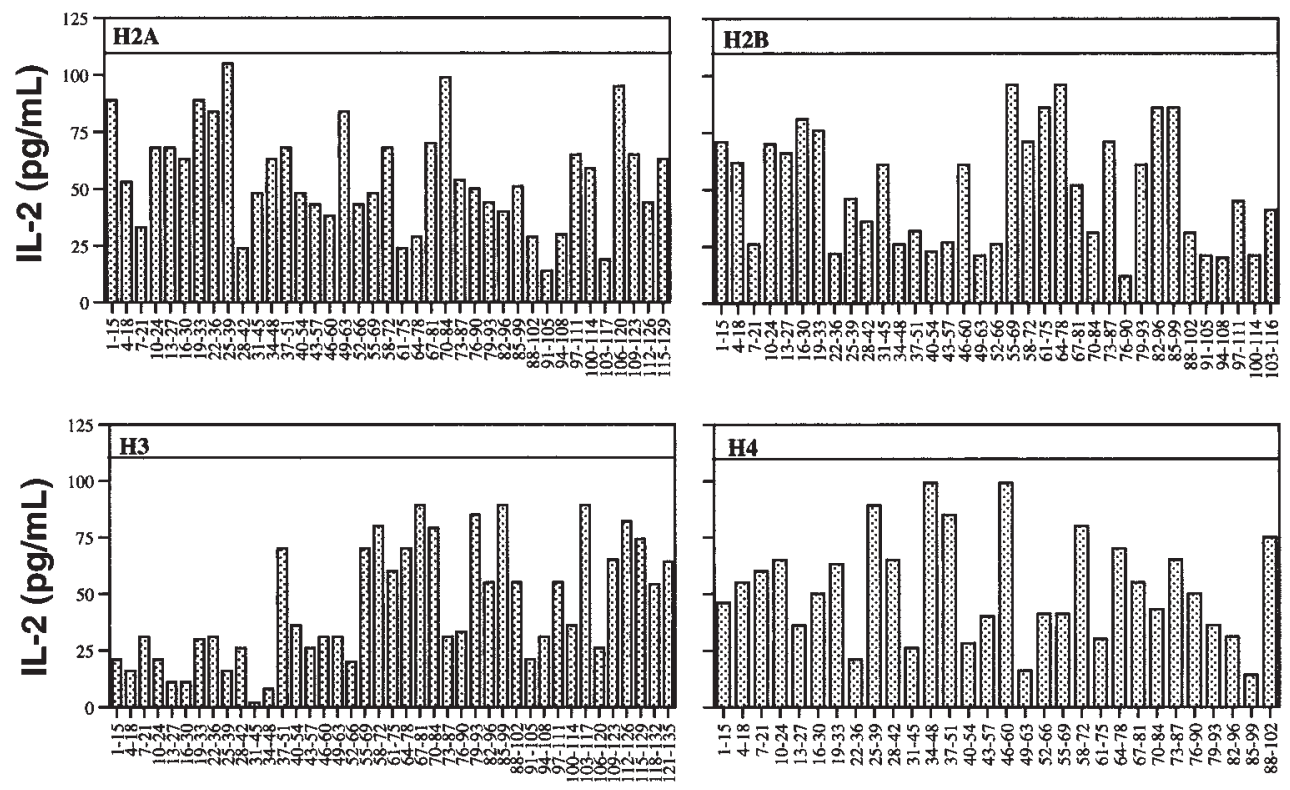

Histone peptide

\section{Figure 4}

IL-2 production by N-JV, a short-term CD4 T-cell line from a representative normal donor to histone peptides using autologous EBV B-cell APCs. The horizontal line in each panel demarcates 3 SD above the mean of background values. None of the normal T-cell lines showed a response to any of the peptides that was 3 SD above their respective background values.
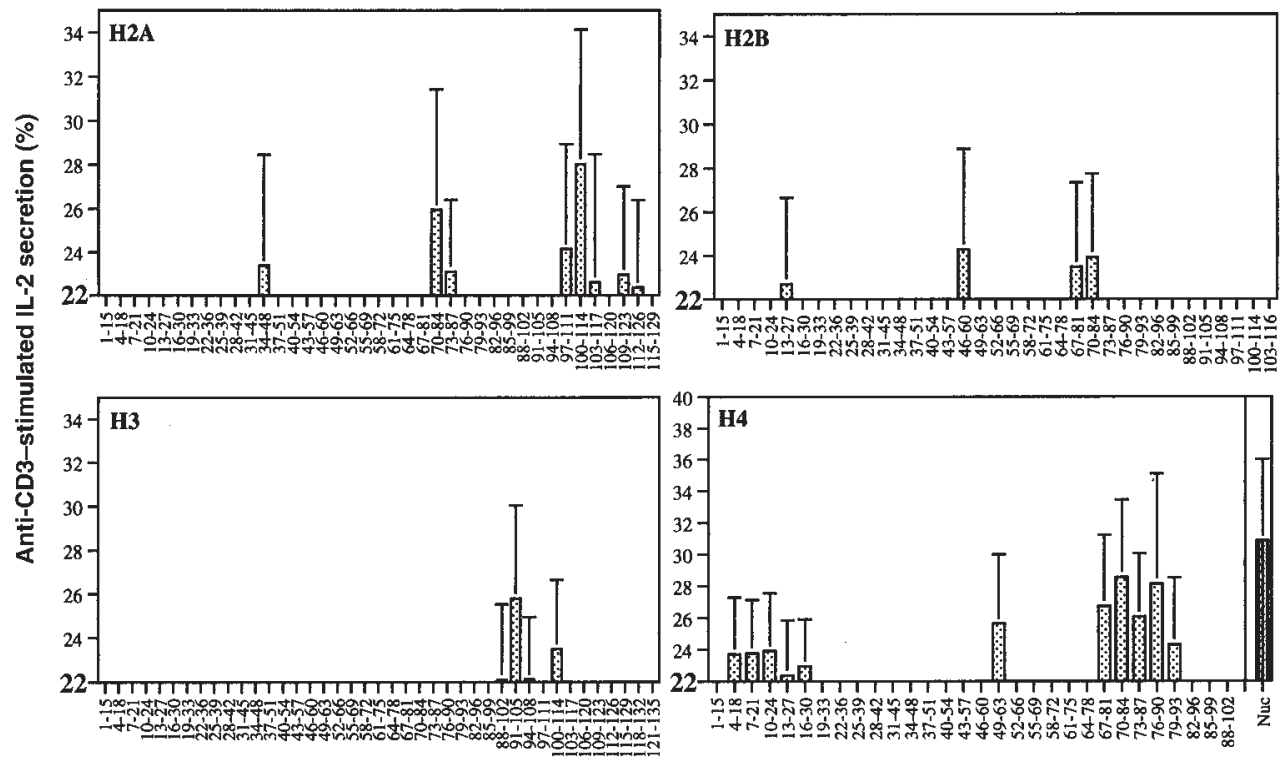

Histone peptide

\section{Figure 5}

Summary of IL-2 production responses of short-term T-cell lines to nucleosomal histone peptides in 10 patients with lupus. The results are expressed as percentages of maximal responses of the T-cell lines stimulated by anti-CD3 mAb. Bars represent mean values from 10 lupus T-cell lines, with error bars in SEM. Values of T cells cultured with autologous EBV B-cell APCs alone were considered as background. The baseline for $y$ axis is set at $22 \%$, which is 3 SD above the mean of background values (14.5\%). A peptide was considered stimulatory when it elicited a positive response above this baseline. For instance, the average of responses of all $10 \mathrm{~T}$-cell lines to $\mathrm{H}_{16-30}$ peptide was $23 \pm 2.6$. All the stimulatory peptides in the panels elicited positive responses in all 10 lupus $\mathrm{T}$-cell lines to levels greater than 3 SD above their respective background values. The extreme right bar in the bottom right $(\mathrm{H} 4)$ panel was the mean value of responses of the 10 lines to whole nucleosome preparation. 


\begin{tabular}{|c|c|c|c|}
\hline Stimulato & ory Region & $\begin{array}{c}\text { 15-mer synthetic } \\
\text { peptide }\end{array}$ & Amino acid sequence \\
\hline $\begin{array}{l}\mathrm{H} 2 \mathrm{~A} \\
\mathrm{H} 2 \mathrm{~A} \\
\mathrm{H} 2 \mathrm{~A}\end{array}$ & $\begin{array}{l}34-48 \\
72-86 \\
97-126\end{array}$ & $\begin{array}{l}\mathrm{H}_{2} \mathrm{~A}_{34-48} \\
\mathrm{H}_{2 A_{72-86}} \\
\mathrm{H}_{2} \mathrm{~A}_{97-111} \\
\mathrm{H}_{2} \mathrm{~A}_{106-120} \\
\mathrm{H}_{112-126}\end{array}$ & $\begin{array}{l}\text { LRKGNYAERVGAGAP } \\
\text { DNKKTRIIPRHLQLA } \\
\text { LGKVTIAQGGVLPNI } \\
\text { GVLPNIQAVLLPKKT } \\
\text { QAVLLPKKTESHHKA }\end{array}$ \\
\hline $\begin{array}{l}\mathrm{H} 2 \mathrm{~B} \\
\mathrm{H} 2 \mathrm{~B} \\
\mathrm{H} 2 \mathrm{~B}\end{array}$ & $\begin{array}{l}13-27 \\
46-60 \\
68-82\end{array}$ & $\begin{array}{l}\mathrm{H}_{2 B_{13-27}} \\
\mathrm{H}_{2 B^{46-60}} \\
\mathrm{H}_{28} \mathrm{~B}_{68-82}\end{array}$ & $\begin{array}{l}\text { GSKKAVTKAQKRDGK } \\
\text { KOVHPDTGISSKAMG } \\
\text { DIFERIAGEASRLAH }\end{array}$ \\
\hline $\begin{array}{l}\text { H3 } \\
\text { H3 }\end{array}$ & $\begin{array}{l}91-105 \\
100-114\end{array}$ & $\begin{array}{l}\mathrm{H} 3_{91-105} \\
\mathrm{H} 3_{100-114}\end{array}$ & $\begin{array}{l}\text { QSSAVMALQEASEAY } \\
\text { EASEAYLVGLFEDTN }\end{array}$ \\
\hline $\mathrm{H} 4$ & $4-30$ & $\begin{array}{l}\mathrm{H} 4_{5-19} \\
\mathrm{H} 4_{14-28}\end{array}$ & $\begin{array}{l}\text { KGGKGLGKGGAKRHR } \\
\text { GAKRHRKVLRDNIQG }\end{array}$ \\
\hline $\begin{array}{l}\mathrm{H} 4 \\
\mathrm{H} 4\end{array}$ & $\begin{array}{l}49-63 \\
67-93\end{array}$ & $\begin{array}{l}\mathrm{H} 4_{49-63} \\
\mathrm{H} 4_{67-81} \\
\mathrm{H} 4_{73-87} \\
\mathrm{H} 4_{79-93}\end{array}$ & $\begin{array}{l}\text { LIYEETRGVLKVFLE } \\
\text { RDAVTYTEHAKRKTV } \\
\text { TEHAKRKTVTAMDVV } \\
\text { KTVTAMDVVYALKRQ }\end{array}$ \\
\hline
\end{tabular}

\section{Figure 6}

A library of histone peptides that correspond to the stimulatory epitope regions identified with lupus T-cell lines and clone DD2. In addition, three 24-mer peptides that overlapped some of these epitopes were used for further studies: $\mathrm{H}_{2} \mathrm{~B}_{10-33}$ (PKKGSKKAVTKAQKKDGKKRKRSR), H4 16-39 (KRHRKVLRDNIQGITKPAIRRLAR), and H471-94 (TYTEHAKRKTVTAMDWYALKRQG). All peptide sequences are identical to those in human histones (GenBank).

aliquots of cells from the same sample gave almost identical results (SD $<5 \%$ ). Some of the nucleosomal peptides caused impressive stimulation of $\mathrm{T}$ cells from the patients with lupus; by contrast, positive responses were rare in the normal subjects (compare Figure 8 with Figure 9). IFN- $\gamma$ and IL-4 responses to nucleosomes and some of their peptides were greater than 10 -fold above background values, and corresponding IL-10 responses were up to 20 -fold higher in some of the patients (Figure 8). These results are highly significant because the frequency of autoantigen-specific responder CD4 T cells was measured by this assay (19). Remarkably, the ability to respond to the nucleosomal peptides was still present in the patients in long-term remission. In fact, responses as a whole were considerably attenuated in the PBMCs of some of the patients with active lupus (A$\mathrm{KJ}$ and $\mathrm{A}-\mathrm{WB})$, possibly owing to prior activation in vivo and exhaustion or desensitization. Interestingly, IL-10 responses to certain nucleosomal peptides were in many cases higher than corresponding anti-CD3 responses, even in the patients in remission; and in some patients, responses to certain peptides were stronger than to the whole nucleosome particle (Figure 8).

In Figure 10, a summary of the percentage of positive responders to a particular nucleosomal peptide among the patients with lupus is shown. Although some cytokine responses showed spreading to many epitopes in a few cases, such as R-DS, R-JE, and A-MC (Figure 8), certain nucleosomal peptides turned out to be recurrent epitopes for the autoimmune $\mathrm{T}$ cells of patients with lupus. Among the patients whose PBMCs were tested and whose $T$ cells were not desensitized, as determined by anti-CD3 stimulation, the incidence of positive responders ranged from $50 \%$ to $100 \%$ to the following autoantigens in the panel: nucleosomes and their longer 24-mer peptides $\mathrm{H}_{2} \mathrm{~B}_{10-33}, \mathrm{H} 4_{16-39}$, and $\mathrm{H}_{41-94}$, as well as the 15-mer nucleosomal peptides $\mathrm{H} 2 \mathrm{~A}_{34-48}, \mathrm{H} 3_{91-105}$ and overlapping $\mathrm{H} 3_{100-114}, \mathrm{H} 4_{14-28}$, which is overlapped by $\mathrm{H}_{46-39}$, and $\mathrm{H}_{49-63}$ (Figure 10).

The type of cytokines that were predominantly produced was influenced in some instances by the autoantigen and in others by the patient's T cells. For example, the ratio of IFN- $\gamma / \mathrm{IL}-10$-positive cells responding to $\mathrm{H} 3_{91-105}$ was 70 in patient R-SS, but the opposite was the case in patient R-HH, in whom the IL$10 /$ IFN- $\gamma$ ratio of response to the same peptide was 10 (derived from Figure 8, after subtraction of respective background values). Similarly, $\mathrm{H}_{49-63}$ induced a stronger IFN- $\gamma$ response in R-SS, but a stronger IL-10 response in A-MC. Overall, 4 of the patients (R-DS, RDW, R-SS, and R-SC) had a higher percentage of IFN$\gamma$-producing cells in response to the peptides; 5 others (R-JE, R-HH, A-MC, A-VS, and A-WB) were skewed more toward IL-10- and/or IL-4-producing cells; 1 patient (R-WG) appeared to favor both IFN- $\gamma$ - and IL10-positive cells (depending on the peptide used for stimulation); and 2 others (R-FN and A-KJ) were poor responders in general. Despite these variations, antiCD3 stimulation overwhelmingly favored IFN- $\gamma$-producing CD4 T-cell response in all cases (12/12). After subtracting background values ("medium"; Figure 8), the ratios of IFN- $\gamma / \mathrm{IL}-10$-positive CD4 T cells ranged from 2.7 to 171 (mean \pm SEM $=58.6 \pm 15.9)$, IFN- $\gamma / \mathrm{IL}-$ 4 from 2.1 to $114.5(20.3 \pm 10.8)$, and IL-2/IL-4 from 0.6 to $24.8(9.7 \pm 2.8)$ upon anti-CD3 stimulation of PBMCs from the 12 patients. Using similar analysis, an IFN- $\gamma$-positive T-cell response was favored in the cases of the following autoantigens: nucleosomes, $\mathrm{H}_{16-39}$, $\mathrm{H} 4_{49-63}, \mathrm{H} 4_{71-94}$, and $\mathrm{H} 3_{91-105}$. The $\mathrm{H} 3_{91-105}$ peptide also stimulated IL-10- and/or IL-4-positive T-cell response among 7 of the 8 responders (Figure 10), but the latter type of cytokine-positive cells was dominant in only 2 patients. In the case of $\mathrm{H}_{2} \mathrm{~B}_{10-33}$ and $\mathrm{H}_{2} \mathrm{~A}_{34-48}$, the majority of the responders were in favor of a relatively stronger IL-10- and/or IL-4-positive T-cell response.

\section{Discussion}

Nucleosomes are one of the major immunogens for autoimmune $T$ cells that drive the production of pathogenic anti-DNA autoantibodies in SLE. Despite the heterogeneity of human lupus and epitope spreading, we were able to find the autoepitopes in core histones of nucleosomes that are recurrently recognized by the autoimmune $T$ cells derived from 23 patients with lupus. We used a representative anti-DNA autoantibody-inducing T-cell clone, as well as short-term T-cell lines from 10 other patients with lupus, to localize the major autoepitopes. While deriving the T-cell lines, we did not stimulate the lupus $T$ cells with any exogenously added nucle- 
a

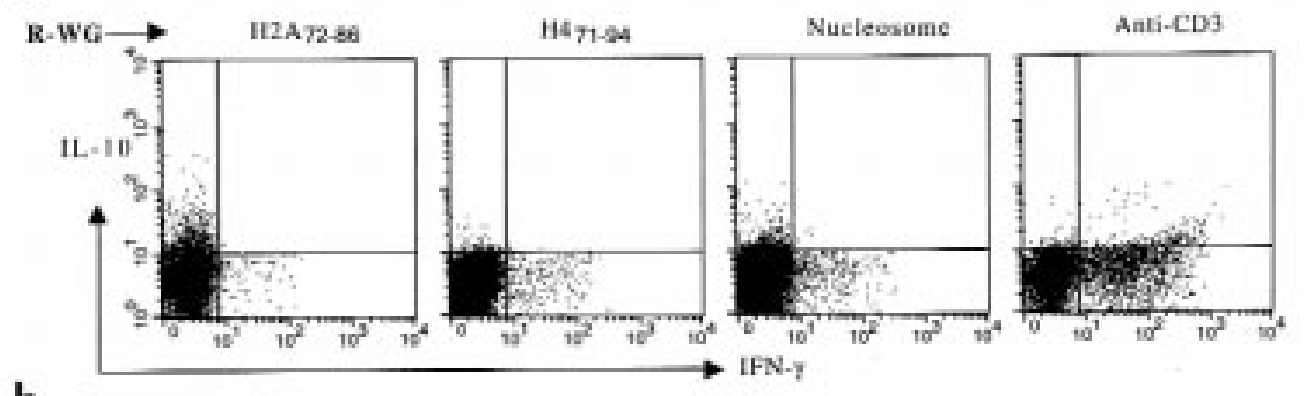

b

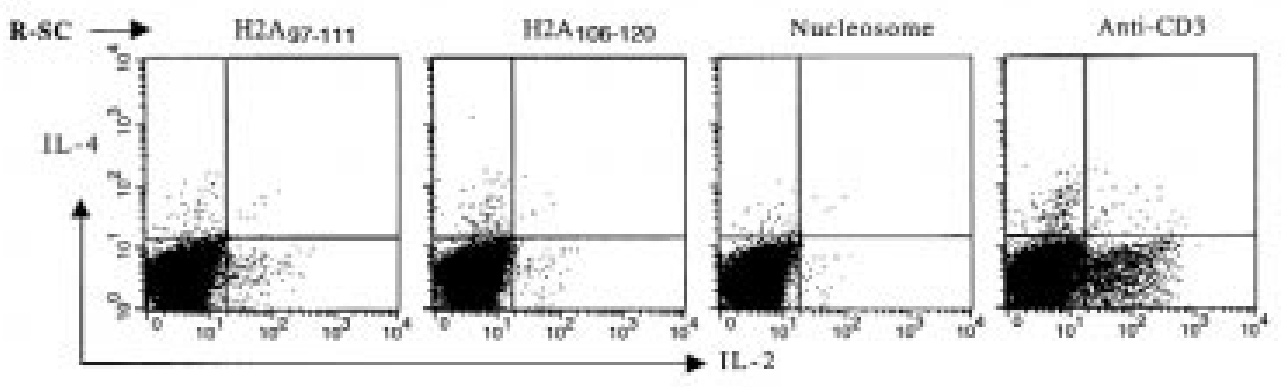

Figure 7

Representative 2-color intracellular cytokine staining of gated $C D 4^{+} \mathrm{T}$ cells freshly obtained from 2 patients with lupus who were in remission (R-WG and R-SC). IFN- $\gamma$ and IL-10 response (a) and IL-2 and IL-4 production (b) in response to stimulation by anti-CD3, nucleosomes, or the histone peptide epitopes. Demarcation of the quadrants was set based on background staining of the T cells cultured in medium alone. Percentage values for the respective cytokine stainings can be found in Figure 8.

osomal peptides. We have previously shown that the onetime expansion to make the lines by anti-CD3, antiCD28, and IL-2 (low dose) stimulation yields T cells that retain the original autoantibody-inducing function and antigenic specificity of the autoimmune $T$ cells of lupus $(2,17,22)$. We confirmed and narrowed down the major autoepitopes further in freshly obtained PBMC T cells from 12 additional patients by a multiparameter flow cytometry assay that detects rapid intracellular accumulation of cytokines after short-term antigenic stimulation $(19,20)$. Proliferation assays or limiting dilution analysis is not suitable for epitope mapping because they involve days of culturing during which activationinduced cell death occurs (24).The advantage of this assay, besides sensitivity and almost immediate analysis of T cells ex vivo, is that only newly synthesized cytokines in response to nucleosomal peptides added to the cultures are detected. Any cytokines synthesized during preactivation of the lupus $T$ cells in vivo would be secreted out of the cells before addition of Brefeldin A, thus reducing background.

Remarkably, the recurrent autoepitopes identified here for the human lupus $\mathrm{T}$ cells, namely $\mathrm{H}_{2} \mathrm{~B}_{10-33}$, $\mathrm{H} 3_{95-105}, \mathrm{H} 4_{16-39}$, and $\mathrm{H} 4_{71-94}$, overlap the major autoepitopes for nephritogenic $\mathrm{T}$ cells in lupus-prone $\mathrm{SNF}_{1}$ mice (7). These peptides, and native nucleosomes, preferentially stimulated IFN- $\gamma$-producing T cells in the patient's PBMCs, as is the case in murine lupus (7). The nephritogenic autoantibodies in murine lupus that fix complement and bind to Fc $\gamma$ receptors in inflammatory cells belong to the IFN- $\gamma$-dependent IgG subclasses
(25-27). The strength of signaling might have induced more of a Th1-type response (28); however, the same epitopes could also induce a Th2 type (IL-10, IL-4) of response in some of the patients, as described in Results. Another feature, the inability of freshly obtained T cells from patients with active lupus to make an IL-2 response, is probably due to prior activation in vivo that desensitized them, because they are known to recover upon resting in vitro (29). However, exceptions are seen here in the case of A-MC or A-VS (IL-4 in the latter), and the ability to respond may depend on the time point when the PBMCs are harvested from patients. This phenomenon is even more striking for IL-10 responses to some of the nucleosomal peptides, which in many cases were much higher than anti-CD3-stimulated responses of the lupus $\mathrm{T}$ cells, even from the patients in remission (Figure 8). For example, the IL-10-positive response of R-WG's CD4 T cells to $\mathrm{H}_{2} \mathrm{~A}_{72-86}$ or $\mathrm{H} 2 \mathrm{~B}_{68-82}$ peptide is 20 -fold or more higher than background, but corresponding anti-CD3 response is only 4.5 -fold higher, and so on, in the case of many of the patients with lupus. However, anti-CD3-induced IFN- $\gamma$ responses were high in T cells from the same samples. Moreover, in the case of patients in remission in whom the $T$ cells have a resting phenotype comparable to normal subjects (17), the preferential IL-10 stimulation by some peptides over anti-CD3, in some of the patients, would suggest nucleosomal autoantigen-specific modulation of cytokine production. The importance of IL-10 and other Th2 cytokines in the pathogenesis of lupus has also been documented, but its mechanism is not known 


\begin{tabular}{|c|c|c|c|c|c|c|c|c|c|c|c|c|c|c|c|c|c|c|c|c|c|c|c|c|c|}
\hline \multicolumn{2}{|c|}{ Patient symbol $\rightarrow$} & \multicolumn{4}{|c|}{ n-wa } & \multicolumn{4}{|c|}{ nos } & \multicolumn{4}{|c|}{ n-se } & \multicolumn{4}{|c|}{$n-w$} & \multicolumn{4}{|c|}{ nut } & \multicolumn{4}{|c|}{ neas } \\
\hline \multicolumn{2}{|c|}{ Cylokines $\rightarrow$} & $\mathrm{NN}_{\mathbf{T}}$ & 210 & sa & at & EW- & E.to & sa & 24 & Inst & e.16 & $\mathrm{Ea}$ & at & Iner & $n \rightarrow \infty$ & E-a & Est & INY & anda & ca & $2-4$ & $F_{T}$ & Lete & 20 & E-A \\
\hline \multirow{16}{*}{$\begin{array}{l}15 \text {-mer } \\
\text { peptide }\end{array}$} & & $a=$ & 214 & $a$ & obl & 525 & $10=0$ & $a c$ & ext & Eas & $=\infty$ & a.t & a.te & bet & sest & est & ara & 041 & or & D.44 & o.te & 000 & a.18 & ats & $a=$ \\
\hline & & $\operatorname{cat}$ & $2 \mathrm{ma}$ & a.10 & 0.18 & D. & 100 & ais & a.16 & nas & 121 & a10 & a.17 & DEr & ear & 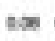 & 908 & 0.25 & 064 & $\infty \omega$ & Q.10 & ant & $a \sqrt{6}$ & agr & $a m$ \\
\hline & & ase & 210 & a.ts & 0.04 & ces & $2 x$ & $|000|$ & asis & on & ent & 28 & 0.14 & o.r & oss & 0 & • & 0.12 & osi & o.ce & a.18 & 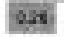 & $\infty$ & 004 & aar \\
\hline & $\operatorname{lex}=$ & $2 \pi$ & $\operatorname{sor}$ & $a b$ & om & t2an & $=9$ & $a d$ & aod & 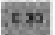 & $6 x^{7}$ & $2+6$ & esta & ent & $\operatorname{sar}$ & 6 & 5 & a.ts & a.ta & $a$, & 021 & $a c e$ & $a \omega$ & as & adr \\
\hline & $\operatorname{man} \mathrm{ras}$ & 00 & ass & a.te & 0.04 & ces & ov & $\operatorname{ans}$ & ace & cat & 031 & 20 & a.11 & 000 & Der & ex & ass & a.te & ose & ace & a.16 & 0.10 & $a n$ & ans & $a \in$ \\
\hline & Has we & $\cos$ & $t+2$ & atb & ait & and & ent & aot & $\omega \infty$ & as & 6.95 & $2=1$ & aiz & o.s & 000 & ov & 6 & a.17 & oes & a.12 : & dat & an & ais & $\bullet$ & ast \\
\hline & Hes ses & eac & $\operatorname{lab}$ & 30 & ant & $\cos$ & t & ast & a.13 & ass & 6 & $2+8$ & $a w$ & 6.09 & 60 & $t a$ & $a c$ & aes 7 & a.16 & $\omega \infty$ & $\overline{a+1}$ & aos & $a \infty$ & aen & ats \\
\hline & Hes an & $D s$ & $a x$ & $90 \pi$ & 9 & a.s & 80 & ses & ats & ax & $\mathrm{es}$ & 874 & and & ase & 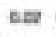 & eat & $a 0$ & 28 & $a x$ & as & a:s & an & $a a s$ & as & $a x$ \\
\hline & Hann & axt & 123 & 200 & dest & $0+1$ & en & $\pm \infty$ & क्2) & 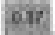 & ons & 12 & $4 x$ & an & as & og & sas & a.16! & ax & $a \infty$ & $9 x$ & $a \infty$ & $32 \pi$ & $a=8$ & 14 \\
\hline & Hat in: & ens. & at & ats & ace & ort & Eq1. & 128 & $2+1$ & 6.4 & 644 & $12 \pi$ & 213 & $a .12$ & 000 & 0.11 & $\operatorname{cas}$ & 2.14 & as & a.13 & ast & $a * 1$ & 25 & 29 & das \\
\hline & $\mathrm{HA}_{\text {, }}$ & e.13 & 13s & son & $a \omega$ & $2: 4$ & ent & sat & 8 & sa & Defl & 676 & adr & ast & sed & e.ta & $\mathrm{ev}$ & 92 & anc & act & art & a:s & as & 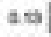 & 34 \\
\hline & "14 & Eif & sut & 100 & aod & 0.94 & one & $1 \mathrm{ar}$ & $20 \pi$ & Q.12 & 0.00 & ov & adr & an & oca & $a n$ & $\mathrm{ens}$ & 210 & 98 & 200 & $a 13$ & $a x p$ & 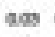 & 900 & 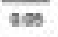 \\
\hline & Hat & e.s & 50 & ax & aat & axi & 0.00 & iva & $\sin$ & 24 & 6.43 & e.r7 & agr & alla & e.1. & e.16 & ont & 20 & a.6 & a.16 & 29 & 210 & aot & 20 & $42 x$ \\
\hline & & en & $b$ & $=0$ & $a d$ & ant & 60 & bat & - & $a=4$ & a.ta & ent & 45 & 0.04 & aca & a.n & ets & 1.5 & at & $\operatorname{an}$ & ast & adr & tas & $a=$ & $\mathrm{tu}$ \\
\hline & Ha net & a.n & D. & nos & 20 & $a x$ & opd & s. & Bal & an & ada & ex & ent & abe & ase & og & 20 & $\mathrm{cs}$ & sat & as & ast & as & 831 & ast & sar \\
\hline & & 0.21 & tat: & $\mid 0.0$ & ast & das & 6as & 0.14 & $2 \pi$ & a.1 & a.16 & 0.14 & cos & ace & 002 & 0.15 & 000 & 134 & $14 \pi$ & 10 & 48 & $\operatorname{can}$ & $\cos$ & 496 & Iat \\
\hline \multirow{3}{*}{$\begin{array}{l}24-\text { mer } \\
\text { peptide }\end{array}$} & & e.24. & aes & en & 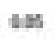 & $10 *$ & 02 & 10.00 & $\mathrm{CO}$ & $=$ & ne & a & $d$ & $\propto$ & as & 0 & ow & Or & as & an & 145 & ist & 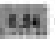 & on & 000 \\
\hline & & 034 & a.t. & e.ts & tat & $2=$ & a.14 & 0.00 & BEA & $=$ & ne & nd & nd & 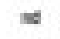 & ne & 0 & 0 & ent & asi & e.11 & 24 & Es & 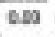 & on & e.ts \\
\hline & 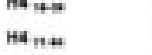 & 6s4 & a.1s & an & $m a$ & $32 \pi$ & a.te & $b o$ & o & al & $\approx$ & at & 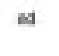 & $\infty$ & $\infty$ & a & abm & $=\pi$ & $=4$ & at & हरास & क्वश & o.1 & Dea & Dos \\
\hline \multicolumn{2}{|c|}{ Nucleosome } & & 4 & 1000 & c & 21 & 10n & a.11 & a. & 8 & ase & a.16 & e & 10 & 199 & 9 & D & $\mu$ & $5 n$ & $\operatorname{lon}$ & (e) & eq & on & a.11 & t \\
\hline \multicolumn{2}{|c|}{ Control peptide $\mathrm{H}^{3}{ }_{\mathrm{n}}$} & a & a.s & Q.14 & 604 & $\pm x$ & ais & 0.01 & 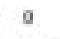 & 24 & $a a^{\prime}$ & bat & a.n & $\operatorname{las}$ & 20 & ace & 00 & e.n & on & 000 & a.t1 & 0.04 & $\infty \omega \theta$ & a. & 006 \\
\hline & 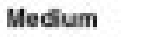 & 3 & ant & 000 & DDa & ent & an & aod & oxe & on & $a+8$ & ace & an & ear & aar & ate & and & bes & ent & B.11 & 000 & abs & beo & and & an \\
\hline & Anti-CD3 & $\theta y$ & ass & 213 & Q.14 & 720 & $a n$ & $n$ & $0, x$ & 750 & 100 & $\operatorname{sen}$ & OBA & $2 n$ & axn & 961 & $a w$ & 187 & 0.45 & na & 0.60 & 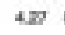 & ace & 316 & aes \\
\hline
\end{tabular}

b

\begin{tabular}{|c|c|c|c|c|c|c|c|c|c|c|c|c|c|c|c|c|c|c|c|c|c|c|c|c|c|}
\hline \multirow{2}{*}{\multicolumn{2}{|c|}{$\begin{array}{l}\text { Patient symbol } \rightarrow \\
\text { Cytokines } \longrightarrow\end{array}$}} & \multicolumn{4}{|c|}{ A.DW } & \multicolumn{4}{|c|}{ Ass } & \multicolumn{4}{|c|}{$A-M C$} & \multicolumn{4}{|c|}{ A-vs } & \multicolumn{4}{|c|}{$A \in K}$, & \multicolumn{4}{|c|}{ A-we } \\
\hline & & wy & L16 & wa & ILt & $V_{T}$ & ans & at & at & $\mathrm{Hr}$ & 16-16 & wa & thet & $\mathrm{WNy}$ & Lid & cat & at & ind & k-10 & hes & E-4 & $\mathbf{T H}$ & $14-16$ & wa & thet \\
\hline 15-mer & $124=0$ & ans & t. & eat & 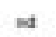 & e.11 & 2.13 & $a$ & ie & ani & 13 & 6.16 & 248 & ate & 23 & $a$ & a & 0.04 & 65 & a.2 & oos & ax & 00 & 000 & $2 n$ \\
\hline \multirow{15}{*}{ peptide } & $\operatorname{mak} \mathrm{ne}$ & ast & 00 & ne & it & 600 & an & $n$ & nd & $a=$ & 0.16 & on & 197 & 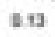 & 0.00 & a.r & en & 0.00 & obs & ar & 010 & $a s$ & a:a & 004 & $a b$ \\
\hline & Men wen & au & a.s & ne & st & 610 & an & nd & nd & $a \infty$ & $1 n$ & eas & 137 & ater & ase & 2.17 & 63 & 0.06 & $\theta 0$ & a.4s & an & aอs & 000 & 000 & $a v$ \\
\hline & $\mathrm{H} 2 \mathrm{~A}=\mathrm{in}$ & ase & $2 x$ & net & nd & e.12 & 2.18 & ad & red & $a x$ & tat & 0.30 & $m$ & e.t & acon & $a$ & ace & oce & cose & 02 & $a \propto 2$ & $a x$ & a.s & $\infty$ & 211 \\
\hline & HeA rous & an & 000 & ne & id & 0.14 & a. 15 & ad & ra & $a 44$ & ent & $o x$ & $24 t$ & en & ar & 000 & 0.12 & 000 & 0.06 & 20 & $a x$ & $a v$ & 4.21 & 000 & $2 u$ \\
\hline & Hes ne & $a=$ & $00 y$ & ne & nd & ors & as 6 & $\infty$ & ad & 26 & 00 & on & 134 & 212 & a.21 & a.t & 6.9 & 000 & 000 & ass & 004 & ast & 0.12 & 806 & 100 \\
\hline & HOS =O & $a=$ & ans & ne & nt & 0.13 & a. & $\infty$ & a & 0.50 & 0.40 & 0 & 130 & 00 & $a x$ & oar & 64 & D.o4 & cbr & an & 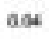 & $a \neq 0$ & ex & 004 & ave \\
\hline & HeQ an & $a \geq$ & $\infty \infty$ & et & st & 0.14 & 2.14 & at & tat & an & 0.8 & en & 101 & 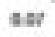 & 90 & $\mathrm{sas}$ & exs & 0.13 & sce & $a m$ & a & $a \infty$ & 813 & 0.12 & ans \\
\hline & Hatin & $a x z$ & oot & $n$ & 4 & sot & a 10 & $\Rightarrow$ & as & 481 & en & $\pi$ & in & 100 & of & 0.12 & 10.4 & ans & ob & $a x$ & dos & $a d$ & ars & Dod & $9: 0$ \\
\hline & Ha twim & $a \Omega$ & $a$ th & 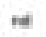 & $\Rightarrow$ & bst & $a x$ & $=4$ & rat & ste & 0.48 & 18 & 483 & 93 & $a+x$ & as & 6.18 & ens & $t \infty$ & $a s$ & $=\pi$ & aar & : & sos & aes \\
\hline & 1144 & ase & as & ed & $\Rightarrow$ & e.12. & 2.14 & a & na & $a=$ & $0 \in$ & en & 484 & $=a$ & $a x$ & oce & s.78 & 604 & ste & 93 & 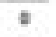 & $a=$ & 616 & Ses & a 15 \\
\hline & Ma & ass & aar & ne & 4 & a & a.t. & 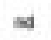 & na & $a n$ & ats & 230 & 2.45 & ats & ats & 004 & E.18 & 6.04 & 580 & 93 & aot & $a n$ & घxा & $B D$ & a $u$ \\
\hline & HA & an & aat & ne & sa & 13 & tes & ad & rat & $a=t$ & $0 s y$ & an & $\tan$ & 40 & at & acs & 0.12 & ax & 60 & as & an & as & 0.14 & ees & tat \\
\hline & Hetwen & $a x$ & oar & ne & id & 60 & 2.13 & ad & na & est & $0 x$ & Ia & 104 & 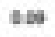 & 0.57 & 0,0 & 0.18 & 0.10 & DEA & an & 0.0 & $a \times$ & 6.24 & $O D$ & a.15 \\
\hline & MA nen & $a s a$ & Q 10 & ne & nd & 000 & 006 & ad & nd & 256 & 0.5 & 1.18 & 10 & 10 & ant & a.t & $6 x$ & $0 \pi$ & Doe & 9.0 & aar & $a \infty$ & 0.13 & o & a.1 \\
\hline & $\mathrm{HA} n \mathrm{nen}$ & ans & as & ne & ne & 0.16 & 13 & ed & ad & $a .26$ & a.11 & iss & $1 \mathrm{se}$ & Ded & $a=$ & 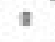 & Doe & 0.04 & Dod & 912 & 003 & ase & arr & ove & c日a \\
\hline \multirow{3}{*}{$\begin{array}{l}\text { 24-mer } \\
\text { peptide }\end{array}$} & mas an & ant & $0, \infty$ & re & ne & $0 . x$ & $e x$ & 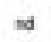 & nd & and & na & na & nd & on & 1.3 & oar & Es & Q10 & DOA & an & $\operatorname{ars}$ & $a=0$ & Q.4 & Doe & 013 \\
\hline & $\mathrm{HA}_{\mathrm{H}} \mathrm{H}$ & iat & 100 & ne & nd & $E H$ & Don & d & ad & sd & w & re & nd & 13 & av2 & 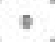 & 00 & $\infty$ & 001 & 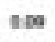 & $a \infty$ & $a s$ & 0.21 & a & 212 \\
\hline & $\mathrm{Hann}$ & 128 & a.os & ie & id & 634 & 211 & 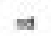 & ad & ad & id & ne & $a$ & an & 132 & ais & 0.8 & 000 & 0.00 & 411 & as & aอ & 000 & 000 & $=06$ \\
\hline \multicolumn{2}{|c|}{ Nucleosame } & 14 & aos & ne & ne & 8.48 & e. 17 & 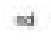 & ad & 13 & t.r. & oxe & 14 & 127 & a.t1 & c & bis & 0.00 & DOA & an & oas & $\operatorname{ax}$ & 0.4 & 000 & a.17 \\
\hline \multicolumn{2}{|c|}{ Control peptide $\mathrm{H}_{3}$ as } & $8 n$ & ads & ne & ra & 9 & $5 x$ & $\Delta$ & a & $a+4$ & $2: 14$ & ese & 694 & tete & $a x$ & $a \omega$ & eat & 00 & ent & 4.17 & ase & $a=$ & est & e.te & tes \\
\hline & Medium & 213 & age & $n$ & na & 698 & (6.1) & a & $a$ & $a x$ & acs & e.18 & ate & sete & $a \geq$ & aon & a.te & ais & sen & 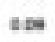 & aa & $a=$ & a: & ax & ses \\
\hline & Anti-cD3 & 613 & as & net & re & ses. & bs & 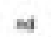 & a & $\pi 3$ & as & 112 & $2 \infty$ & $2 n$ & $a$ & $\operatorname{tas}$ & 0 & 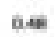 & bes & an & axt & ae & $a=$ & 160 & $=10$ \\
\hline
\end{tabular}

Figure 8

Flow cytometry results of intracellular cytokine staining of viable, $\mathrm{CD} 4^{+}$-gated $\mathrm{T}$ cells from peripheral blood of all the patients with lupus. T-cell response to a peptide epitope was considered positive when the percentage of positive cells was twice the background (medium alone) and at least $0.2 \%$ of the total viable $\mathrm{CD} 4{ }^{+} \mathrm{T}$ cells were stained positive. Positive response is shown in shaded and bold numbers. nd = not done. 


\begin{tabular}{|c|c|c|c|c|c|c|c|c|c|c|c|c|c|c|c|c|c|c|c|c|c|c|c|c|c|c|c|c|}
\hline \multirow{2}{*}{$\begin{array}{l}\text { Oonor Symbol } \longrightarrow \\
\text { Cytekine } \longrightarrow\end{array}$} & \multicolumn{4}{|c|}{$N C A$} & \multicolumn{4}{|c|}{ NAB } & \multicolumn{4}{|c|}{ N-8T } & \multicolumn{4}{|c|}{$N-\theta$} & \multicolumn{4}{|c|}{ NuL } & \multicolumn{4}{|c|}{ NEV } & \multicolumn{4}{|c|}{ Nwo } \\
\hline & 4 & i E-a & K-4 & $a$ & nas & 2.16 & its & $5-4$ & 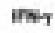 & T L -10 & ea & at & $\mathrm{N}$ & ilata & that & st & $\mathrm{W}-\mathrm{g}$ & q 2,18 & at & E-A & inn-y & t 2.0 & eat & at & $\mathrm{rm}=$ & a $6-1 \mathrm{a}$ & E-a & Lat \\
\hline 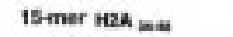 & ase & ess & adr & Q.t & $a s$ & ats & sea & $a g t$ & bes & as & ans & 606 & ar & bos & as & & & a.s & b.t? & & $\infty$ & sat & at & 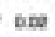 & ot & pese & $9 a$ & as \\
\hline man now & ace & obn & agr & am & $a \infty$ & as4 & Dod & 82 & Des & as & as & Dos & $\infty$ & Dos & 9as & ace & $m$ & $a x$ & $10 \mathrm{om}$ & an & ent & 30 & $a d$ & 0 & agr & on & asr & 0.14 \\
\hline 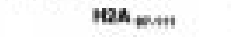 & ace & DDR & $a \infty$ & om & $9 \infty$ & 000 & DDQ & 905 & 0 & nes & 004 & Dof & ar & opo & 0 & $a$ & 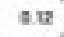 & ax & 0 & 92 & one & av & $a c$ & on & 101 & 0 & a.x & $10 x$ \\
\hline Hat ins & 100 & 000 & ase & ace & 103 & 000 & oon & arr & Don & $\operatorname{tac}$ & 001 & 。 & as & 000 & $\ln$ & $a c e$ & 00 & $a x$ & 0.14 & as & oce & 128 & an & 0 & 0 & ove & 202 & 2004 \\
\hline M2A mote & 100 & $\mathrm{ODH}$ & ast & 001 & 9.6 & ox & 000 & ast & oxe & ons & 001 & 0.06 & 001 & 008 & 106 & a & $\cos$ & ax & one & a.16 & Q.15 & 19 & ar & on & 00 & 0.04 & 2.6 & 8 ars \\
\hline H28 ant & 200 & Ood & $a .28$ & 001 & 100 & 0.21 & ota & 000 & ce & as & 000 & 000 & 14 & 0.17 & 0 & 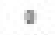 & 10 & acs & 0 & $a c s$ & 0.06 & $a 0$ & $\alpha \infty$ & 000 & $\alpha$ & 000 & as & s a.n \\
\hline H2B $=0$ & 000 & ODA & $a s$ & 0.01 & aat & 000 & ODe & ase & 0.06 & aso & 0.4 & Oba & $a 0 s$ & 006 & ase & 0.12 & as & att & Q.ta & $a=$ & 0.06 & ang & a.t & ase & 0.01 & 000 & 2.06 & 6 ast \\
\hline $\mathrm{H} 2 \mathrm{~B}=\mathrm{An}$ & $0.0 y$ & 0.12 & ast & 000 & $10 x$ & 0.21 & obe & $a d$ & 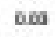 & ast & 0.04 & 6.64 & aos & 0.66 & - & 000 & \pm 2 & att & 060 & a.so & bes & D & at & 0 & בay & o. & $a x$ & a.13 \\
\hline H & 140 & o & an & a & $a x$ & at & 6.14 & $a=0$ & 60 & atr & ant & 6.14 & 8 & oce & ans & क्स & ate & $a x$ & DES & $a \div 0$ & 6.6 & as & a & 604 & $a x$ & ofn & ase & 4 0.6 \\
\hline$=$ & 100 & Bes & adr & aen & at & aos & $\operatorname{sen}$ & as & 6 & 40 & ase & bes & aat & 606 & ant & ax & ast & $a c$ & eat & $10 \times 0$ & e.11 & as & 4a & 6.4 & aos & 6.56 & $a=$ & 0.00 \\
\hline & $\infty$ & Ses & asa & an & $a x$ & acs & $\operatorname{sen}$ & $a c$ & 600 & as & ace & 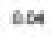 & $a \alpha$ & 600 & as & acs & $a x$ & an & a & asp & e.17 & 2.40 & a & boa & a & 600 & $a=$ & es \\
\hline $\mathrm{H4}=\mathrm{at}$ & â & 60 & $a x$ & an & $a d$ & ace & ses & $a n$ & a & atar & aco & $\mathrm{Eb}$ & 10 & 0.17 & ast & aळ & $=4$ & at & ben & aar & 65 & ast & $a \omega$ & 600 & acs & ofn & $a \infty$ & ase \\
\hline H & aco & bat & adr & aos & ase & abs & $0 \in$ & $a+0$ & 600 & ear & ats & e.16 & $a 04$ & bat & abe & aca & 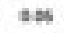 & ant & tas & a a & E.16 & $a \infty$ & ate & 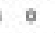 & in & a & as & 4 as \\
\hline M4 est & abs & $\mathrm{sen}$ & $a a$ & $a$ & $=06$ & are & DDA & an & $B D$ & $=2$ & and & soce & an & bes & sat & ant & $=0$ & aos & D.14 & $a=$ & மக & as & a.t & DD & $a 94$ & कв & 30 & ase \\
\hline & acs & pos & $9 a$ & aw & tar & an & Dep & $a d a$ & se & ase & an & a & as & Dos & ast & acs & est & $a=$ & 0.12 & $2 \pi$ & to & as & an & a & as & 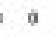 & 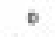 & a \\
\hline n & $a$ & ses & ast & as & $\Delta \infty$ & ase & sea & 9 & $=$ & ast & ans & 60 & s & ass & ast & ans & 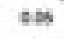 & ats & bas & A & 0 & $a \infty$ & $a c$ & a & at & b & $a \infty$ & son \\
\hline . & & r & & 9 & & 0 & DER & & & I & 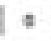 & & & D.15 & tos & & & at & one & & & sts & 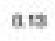 & & is & & 18 & 1 \\
\hline 3 & aco & Dom & $\sec$ & $a$ & & ans & bee & $a s$ & & $\operatorname{ses}$ & $a m$ & & & obs & $\operatorname{sen}$ & ad & & $a c$ & bes & $a \infty$ & Bat & s 16 & am & tom & and & ece & $\mathrm{ant}$ & a \\
\hline & $a c 0$ & e.1n & 40 & $a c$ & nos & 94 & Dod & 0 & 000 & $\cos$ & sos & D & 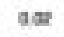 & 000 & 50 & a & $\infty$ & 20 & ood & a & ore & $n=n$ & $a c$ & a & 90 & ow & $a \infty$ & a.14 \\
\hline & $7 \pi$ & on & 12 & 00 & 3 & 00 & 100 & as & 62 & 200 & 100 & on & 124 & 000 & 152 & 0.14 & 104 & as & sst & 160 & 206 & & 100 & 0.00 & 5.34 & 0.68 & 322 & 20.19 \\
\hline
\end{tabular}

\section{Figure 9}

Flow cytometry results of intracellular cytokine staining of CD4 T cells from all the normal subjects. A positive response is displayed, as in Figure 8. The normal T cells did not show a positive response to the longer (24-mer) peptides (data not shown).

(30-32). Thus, nucleosomes may not elicit a straightforward Th1 or Th2 type of response.

Remarkably, T-cell responses to nucleosomes and their peptide epitopes were detected in vitro in all 13 patients with inactive lupus, although their disease was in longterm remission and their serum anti-DNA antibody levels were not elevated. The peptides were probably not being presented in vivo in the patients with inactive lupus, owing to lack of an adequate number of competent APCs, particularly anti-DNA B cells. Moreover, if the numbers or functional activity of autoimmune B cells are diminished during remission, autoantibody production would not occur even if T-cell help were provided, as we have shown in anti-CD40 ligand antibody-treated mice with lupus (16). Most importantly, however, the ability to respond to nucleosomal peptides is not sufficient for full helper competence of lupus T cells. Indeed $\mathrm{T}$ cells from patients with inactive lupus do not help in anti-DNA autoantibody production (1), although they respond to nucleosomes in vitro as shown here. In lupusprone mice, $\mathrm{T}$ cells responsive to nucleosomes are expanded very early in life, but the ability of the same nucleosome-specific T cells to help in the production of pathogenic anti-DNA autoantibodies appears several months later, along with an appearance of anti-DNA autoantibodies in serum of the animals (6). Thus, additional signals and maturational events might be required for the specialized function of helping in pathogenic autoantibody production $(23,33)$. Similar to a lowered threshold for expression of CD40 ligand (17), an expanded number of $\mathrm{T}$ cells that can respond to nucleosomal peptides upon exposure in vitro is another latent, genetically programmed defect that we have unmasked in the patients in remission. This is not surprising, because multiple susceptibility genes and multiple steps are involved in the production of pathogenic autoantibodies and development of lupus nephritis.

Although the TCR repertoire of the pathogenic Th cells may become diverse with "epitope spreading" as the disease progresses (34), primary immunodominant autoepitopes could be identified, probably owing to the considerable cross-reactivity that exists in TCRMHC/peptide interactions (7, 22, 35-42). Indeed, individual TCRs of the pathogenic autoantibody-inducing Th cells of lupus recognize more than 1 nucleosomal peptide epitope in a promiscuous or degenerate fashion and in the context of diverse class II molecules $(7,22)$. High-affinity interactions between the lupus TCRs and MHC-nucleosomal peptide complex due to reciprocally charged residues probably overcome the requirement for MHC restriction, but not MHC dependence (22). Thus, a single nucleosomal epitope could possibly tolerize a spectrum of lupus Th cells; and indeed, tolerization with any one of the major nucleosomal peptide epitopes for autoimmune Th cells in murine lupus can diminish pathogenic autoantibody production across the board (tolerance spreading) and delay the development of nephritis or halt the progression of established disease (23). Moreover, the pathogenic Th cells of lupus are also multipotent in helper activity. Tolerization of such Th cells could deprive multiple autoimmune B cells of help $(3,26,23)$. Importantly, we show here that similar autoepitopes are also recognized by human lupus T cells. Interestingly, the recurrent T-cell autoepitopes of human lupus (Figure 10) fall within histone regions that are also targeted by lupus autoantibodies (43-45). The overlapping of epitopes for autoimmune Th cells and B cells makes $\mathrm{H}_{16-39}$ a highly efficient tolerogen for therapy of murine lupus nephritis (23). Furthermore, the nucleosomal autoepitopes for human 


\begin{tabular}{|c|c|c|c|c|c|}
\hline \multirow[b]{2}{*}{ Cytokines } & \multirow[b]{2}{*}{$\rightarrow$} & \multicolumn{4}{|c|}{ Positive responderstotal tested } \\
\hline & & $\mathrm{FN}_{7}$ & fL-10 & $\mathbf{L}-2$ & IL-4 \\
\hline \multirow{16}{*}{$\begin{array}{l}\text { 15-mer } \\
\text { peptides }\end{array}$} & $\operatorname{HeA}_{34}=$ & 410 & $\$ 10$ & 17 & 310 \\
\hline & HeA now & vo & เาอ & 0 & 210 \\
\hline & rea smin & 210 & y10 & at & $2 / 10$ \\
\hline & HeA $=18$ & 210 & vito & a & 396 \\
\hline & Hea noin & 2410 & $4+a$ & a & $1 / 90$ \\
\hline & res an & vito & 210 & 17 & 470 \\
\hline & $\mathrm{Heg}=0$ & 9 & 310 & 4 & 870 \\
\hline & 100 esear & vio & 210 & AT & 210 \\
\hline & $\mathrm{Ha}$ min & S10 & 470 & $2 / 7$ & mo \\
\hline & $\mathrm{Hg}$ ners & 4TO & sise & 37 & 640 \\
\hline & $\mathrm{HA}+\mathrm{W}$ & 310 & 310 & MT & 430 \\
\hline & $\mathrm{H} 4$ was & 470 & Sot & 27 & 170 \\
\hline & $\mathrm{H} 4$ tase & 2ne & 310 & v7 & 240 \\
\hline & $\mathrm{HA}$ se & 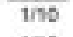 & 2า0 & v7 & $1 / 10$ \\
\hline & $\mathrm{H} 4 \mathrm{ne}$ & 175 & 870 & 17 & 310 \\
\hline & $\mathrm{H} 4 \mathrm{n}=\mathrm{a}$ & 2า10 & 210 & 17 & $2 / 10$ \\
\hline \multirow{3}{*}{$\begin{array}{l}\text { 24-mer } \\
\text { peptides }\end{array}$} & $\mathrm{H} 2 \mathrm{~B}$ = & 37 & 47 & 0 & 27 \\
\hline & $\mathrm{H} 4 \mathrm{san}$ & 27 & 27 & 0 & 0 \\
\hline & Hen & $\pi \pi$ & 27 & 0 & 27 \\
\hline \multicolumn{2}{|c|}{ Nucleosome } & จ10 & 510 & $a$ & 310 \\
\hline \multicolumn{2}{|c|}{ Control pestide H3 nar } & 0 & $1 / 10$ & $1 / 7$ & $1 / 10$ \\
\hline
\end{tabular}

\section{Figure 10}

Frequency of positive responders to the histone autoepitopes among the patients with lupus shown in Figure 8. Bold and shaded numbers highlight when $50 \%$ or more responded to a particular epitope; bold and italics represent at least $40 \%$ responders. These epitopes were also recognized by $\mathrm{T}$-cell lines and clones from other lupus patients (Figures 1-6). ${ }^{A}$ Assays could not be done in all cases owing to lack of sufficient PBMCs. The responses of certain lupus $T$ cells were poor, judging from their anti-CD3 response, and those are also excluded from the total.

lupus $\mathrm{T}$ cells have multiple DR-binding motifs (Figure 11). Thus, their recognition by autoimmune $T$ cells might also be MHC dependent (Figure 2b), but unrestricted (22), suggesting that they could be used for tolerogenic therapy across diverse HLA-DR alleles. NonMHC genes within the MHC locus, such as those for
TNF or for C4A null allele, rather than genes for any particular MHC molecule, are probably directly responsible for lupus susceptibility $(46,47)$.

Thus, identification of major nucleosomal peptide autoepitopes for the $T$ cells of human lupus might be important for understanding how such autoimmune $\mathrm{T}$ cells arise, for tracking such $\mathrm{T}$ cells using peptideMHC tetramers, for identifying molecular mimics in environmental pathogens, and for developing antigen-specific therapy.

\section{Acknowledgments}

We thank R. Ramsey-Goldman for providing blood from one of the new patients included in this study, and A. McCoy for helping in sample collection. This work was supported by grants from the National Institutes of Health (RO1-AR39157, AR46309, and AI41985) and the Arthritis Foundation to S.K. Datta. A. Kaliyaperumal was partly supported by a Career Development Award from SLE Foundation.

\footnotetext{
1. Shivakumar, S., Tsokos, G.C., and Datta, S.K. 1989. T cell receptor $\alpha / \beta$ expressing double negative (CD4-/CD8-) and CD4+ T helper cells in humans augment the production of pathogenic anti-DNA autoantibodies associated with lupus nephritis. J. Immunol. 143:103-112.

2. Rajagopalan, S., Zordan, T., Tsokos, G.C., and Datta, S.K. 1990. Pathogenic anti-DNA autoantibody inducing $T$ helper cell lines from patients with active lupus nephritis: isolation of CD4-/CD8- T helper cell lines that express the gamma/ $\delta$ T-cell receptor. Proc. Natl. Acad. Sci. USA. 87:7020-7024.

3. Desai-Mehta, A., Mao, C., Rajagopalan, S., Robinson, T., and Datta, S.K. 1995. Structure and specificity of T-cell receptors expressed by pathogenic anti-DNA autoantibody-inducing T cells in human lupus. J. Clin. Invest. 95:531-541.

4. Sainis, K., and Datta, S.K. 1988. CD4+ T cell lines with selective patterns of autoreactivity as well as CD4-/CD8- T helper cell lines augment the production of idiotypes shared by pathogenic anti-DNA autoantibodies in the NZB $\times$ SWR model of lupus nephritis. J. Immunol. 140:2215-2224.

5. Adams, S., Leblanc, P., and Datta, S.K. 1991. Junctional region sequences of T-cell receptor $\beta$ chain genes expressed by pathogenic anti-DNA autoantibody-inducing T helper cells from lupus mice: possible selection by cationic autoantigens. Proc. Natl. Acad. Sci. USA. 88:11271-11275.

6. Mohan, C., Adams, S., Stanik, V., and Datta, S.K. 1993. Nucleosome: a major immunogen for the pathogenic autoantibody-inducing $\mathrm{T}$ cells of lupus. J. Exp. Med. 177:1367-1381.
}

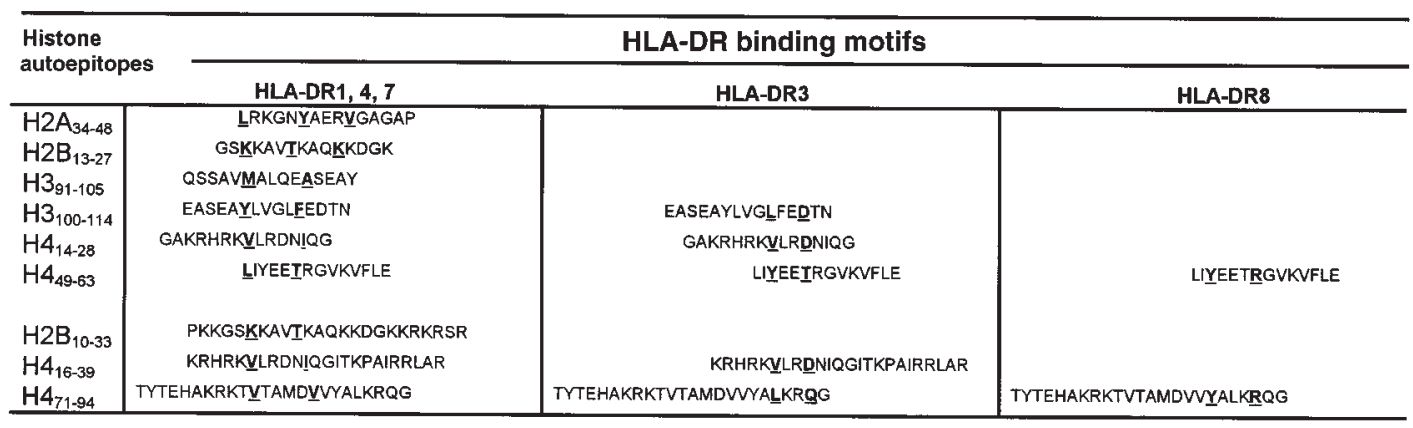

\section{Figure 11}

Multiple HLA-DR binding motifs in histone autoepitopes. The autoepitopes that are recurrently recognized by human lupus T cells (Figure 10) were aligned to various HLA-DR motifs published previously (48-50): HLA-DR1, DR4, DR7: [ LIVMF ] XXXX [ STPALIVMC]; [RKHLIY] $X X X X$ [YTNQCDERSW] XXX AMVKWLHYIFP; [RKHLIY] XXX [YTNQCDERSW] XXX AMVKWLHYIFP. HLA-DR3: [FILVY] XX [DNQT]. HLADR8: [FIVLY] XXX [HKR]. Any single amino acid inside the brackets is one of the most probable anchor residues at that position of the motif. In each of the histone autoepitopes, the corresponding residues are highlighted by bold and underlined letters. $X$ indicates that any of the 20 amino acids can be present in that position, and also represents an individual amino acid position in the sequence. In addition to the motifs indicated here, $\mathrm{H}_{71-94}$ contains multiple motifs for HLA-DR1,3,4,7,8 and also HLA-DR5. 
7. Kaliyaperumal, A., Mohan, C., Wu, W., and Datta, S.K. 1996. Nucleosomal peptide epitopes for nephritis-inducing $\mathrm{T}$ helper cells of murine lupus. J. Exp. Med. 183:2459-2469.

8. Voll, R.E., et al. 1997. Histone-specific Th0 and Th 1 clones derived from systemic lupus erythematosus patients induce double-stranded DNA antibody production. Arthritis Rheum. 40:2162-2171.

9. Kramers, C., et al. 1994. Anti-nucleosome antibodies complexed to nucleosomal antigens show anti-DNA reactivity and bind to rat glomerular basement membrane in vivo. J. Clin. Invest. 94:568-577.

10. Burlingame, R.W., Boey, M.L., Starkebaum, G., and Rubin, R.L. 1994 The central role of chromatin in autoimmune responses to histones and DNA in systemic lupus erythematosus. J. Clin. Invest. 94:184-192.

11. Bernstein, K.A., DiValerio, R., and Lefkowith, J.B. 1995. Glomerular binding activity in MRL lpr serum consists of antibodies that bind to a DNA/histone/type IV collagen complex. J. Immunol. 154:2424-2433.

12. Chabre, H., et al. 1995. Presence of nucleosome-restricted antibodies in patients with systemic lupus erythematosus. Arthritis Rheum. 38:1485-1491.

13. Casciola-Rosen, L.A., Anhalt, G., and Rosen, A. 1994. Autoantigens targeted in systemic lupus erythematosus are clustered in two populations of surface structures on apoptotic keratinocytes. J. Exp. Med. 179:1317-1330.

14. Mevorach, D., Zhou, J.L., Song, X., and Elkon, K.B. 1998. Systemic exposure to irradiated apoptotic cells induces autoantibody production. $J$. Exp. Med. 188:387-392.

15. Ray, S.K., Putterman, C., and Diamond, B. 1996. Pathogenic autoantibodies are routinely generated during the response to foreign antigen: a paradigm for autoimmune disease. Proc. Natl. Acad. Sci. USA. 93:2019-2024

16. Mohan, C., Shi, Y., Laman, J.D., and Datta, S.K. 1995. Interaction between CD40 and its ligand gp39 in the development of murine lupus nephritis. J. Immunol. 154:1470-1480.

17. Desai-Mehta, A., Lu, L., Ramsey-Goldman, R., and Datta, S.K. 1996. Hyperexpression of CD40 ligand by B and T cells in human lupus and its role in pathogenic autoantibody production. J. Clin. Invest. 97:2063-2073.

18. Liang, M.H., Socher, S.A., Larson, M.G., and Schur, P.H. 1989. Reliability and validity of six systems for the clinical assessment of disease activity in systemic lupus erythematosus. Arthritis Rheum. 32:1107-1118.

19. Waldrop, S.L., Pitcher, C.J., Peterson, D.M., Maino, V.C., and Picker, L.J. 1997. Determination of antigen-specific memory/effector CD4+ T cell frequencies by flow cytometry. J. Clin. Invest. 99:1739-1750.

20. Openshaw, P., et al. 1995. Heterogeneity of intracellular cytokine synthesis at single-cell level in polarized $\mathrm{T}$ helper 1 and $\mathrm{T}$ helper 2 populations. J. Exp. Med. 182:1357-1367.

21. Estcourt, C., et al. 1997. Flow cytometric assessment of in vivo cytokineproducing monocytes in HIV-infected patients. Clin. Immunol. Immunopathol. 83:60-67.

22. Shi, Y., et al. 1998. Promiscuous presentation and recognition of nucleosomal autoepitopes in lupus: role of autoimmune $\mathrm{T}$ cell receptor alpha chain. J. Exp. Med. 187:367-378.

23. Kaliyaperumal, A., Michaels, M.A., and Datta, S.K. 1999. Antigen-specific therapy of murine lupus nephritis using nucleosomal peptides: tolerance spreading impairs pathogenic function of autoimmune $\mathrm{T}$ and $\mathrm{B}$ cells. J. Immunol. 162:5775-5783.

24. Bieganowska, K.D., et al. 1997. Direct ex vivo analysis of activated, Fassensitive autoreactive T cells in human autoimmune disease. J. Exp. Med. 185:1585-1594

25. Gavalchin, J., and Datta, S.K. 1987. The NZB $\times$ SWR model of lupus nephritis. II. Autoantibodies deposited in renal lesions show a restricted idiotypic diversity. J. Immunol. 138:138-148.

26. Peng, S.L., Moslehi, J., and Craft, J. 1997. Roles of interferon-gamma and interleukin-4 in murine lupus. J. Clin. Invest. 99:1936-1946.

27. Balomenos, D., Rumold, R., and Theofilopoulos, A.N. 1998. Interferon- gamma is required for lupus-like disease and lymphoaccumulation in MRL-lpr mice. J. Clin. Invest. 101:364-371.

28. Tao, X., Constant, S., Jorritsma, P., and Bottomly, K. 1997. Strength of TCR signal determines the costimulatory requirements for Th1 and Th2 CD4+ T cell differentiation. J. Immunol. 159:5956-5963.

29. Linker-Israeli, M. 1992. Cytokine abnormalities in human lupus. Clin. Immunol. Immunopathol. 63:10-12.

30. Ishida, H., et al. 1994. Continuous administration of anti-interleukin 10 antibodies delays onset of autoimmunity in NZB/W F1 mice. J. Exp. Med. 179:305-310.

31. Llorente, L., et al. 1995. Role of interleukin 10 in the B lymphocyte hyperactivity and autoantibody production of systemic lupus erythematosus. J. Exp. Med. 181:839-844.

32. Nakajima, A., Hiroshe, S., Yagita, H., and Okomura, K. 1997. Roles of IL4 and IL-12 in the development of lupus in NZB/W F1 mice. J. Immunol. 158:1466-1472.

33. Yung, R., et al. 1996. Mechanisms of drug-induced lupus. II. T cells overexpressing lymphocyte function-associated antigen 1 become autoreactive and cause a lupus like disease in syngeneic mice. J. Clin. Invest. 97:2866-2871.

34.Craft, J., and Fatenejad, S. 1997. Self antigens and epitope spreading in systemic autoimmunity. Arthritis Rheum. 40:1374-1382.

35. Wucherpfennig, K., and Strominger, J.L. 1995. Molecular mimicry in T cell mediated autoimmunity: viral peptides activate human $\mathrm{T}$ cell clones specific for myelin basic protein. Cell. 80:695-705.

36. Evabold, B.D., et al. 1995. Specific T cell recognition of minimally homologous peptides: evidence for multiple endogenous ligands. Immunity. 2:655-663.

37. Bhardwaj, V., Kumar, V., Geysen, H.M., and Sercarz, E.E. 1993. Degenerate recognition of a dissimilar antigenic peptide by myelin basic proteinreactive T cells. J. Immunol. 151:5000-5010.

38. Mason, D. 1998. A very high level of crossreactivity is an essential feature of the T-cell receptor. Immunol. Today. 19:395-404.

39. Hemmer, B., et al. 1998. Predictable TCR antigen recognition based on peptide scans leads to the identification of agonist ligands with no sequence homology. J. Immunol. 160:3631-3636.

40. Singh, R.R., Hahn, B.H., Tsao, B.P., and Ebling, F.M. 1998. Evidence for multiple mechanisms of polyclonal $\mathrm{T}$ cell activation in murine lupus. $J$. Clin. Invest. 102:1841-1849.

41. Kuchroo, V.K., et al. 1994. A single TCR antagonist peptide inhibits experimental allergic encephalomyelitis mediated by a diverse TCR repertoire. J. Immunol. 153:3326-3336.

42. Garcia, K.C., et al. 1998. Structural basis of plasticity in T cell receptor recognition of a self peptide-MHC antigen. Science. 279:1166-1172.

43. Stemmer, C., Briand, J.-P., and Muller, S. 1997. Mapping of linear histone regions exposed at the surface of the nucleosome in solution. J. Mol. Biol. 273:52-60.

44. Monestier, M., and Kotzin, B.L. 1992. Antibodies to histones in systemic lupus erythematosus and drug-induced lupus syndromes. Rheum. Dis. Clin. North Am. 18:415-436.

45. Stemmer, C., et al. 1996. Dual reactivity of several monoclonal antinucleosome antibodies for double stranded DNA and a short segment of histone H3. J. Biol. Chem. 271:21257-21261.

46. Vyse, T.J., and Kotzin, B.L. 1998. Genetic susceptibility to systemic lupus erythematosus. Annu. Rev. Immunol. 16:261-292.

47. Morel, L., and Wakeland, E.K. 1998. Susceptibility to lupus nephritis in the NZB/NZW model system. Curr. Opin. Immunol. 10:718-725.

48. Southwood, S., et al. 1998. Several common HLA-DR types share largely overlapping peptide binding repertoires. J. Immunol. 160:3363-3373.

49. Chicz, R.M., et al. 1993. Specificity and promiscuity among naturally processed peptides bound to HLA-DR alleles. J. Exp. Med. 178:27-47.

50. Chicz, R.M., et al. 1992. Predominant naturally processed peptides bound to HLA-DR1 are derived from MHC-related molecules and are heterogeneous in size. Nature. 358:764-768. 